\title{
BCL7A wt Allele
}

National Cancer Institute

\section{Source}

National Cancer Institute. BCL7A wt Allele. NCI Thesaurus. Code C54373.

Human BCL7A wild-type allele is located in the vicinity of 12 q24.13 and is approximately $40 \mathrm{~kb}$ in length. This allele encodes B-cell CLL/lymphoma 7 family member A protein. Expression of the allele is altered in non-Hodgkin lymphoma patients by a three-way translocation $\mathrm{t}(8 ; 14 ; 12)(\mathrm{q} 24.1 ; \mathrm{q} 32.3 ; \mathrm{q} 24.1)$ with the MYC gene and the immunoglobulin $\mathrm{H}$ locus. 